University of Nebraska - Lincoln

DigitalCommons@University of Nebraska - Lincoln

Agronomy \& Horticulture - Faculty Publications

Agronomy and Horticulture Department

$1-17-1969$

Sweetclover-Weevil Feeding Deterrent B: Isolation and Identification

\author{
W. R. Akeson \\ USDA-ARS \\ H.J. Gorz \\ University of Nebraska-Lincoln \\ Francis A. Haskins \\ University of Nebraska-Lincoln, fhaskins@neb.rr.com
}

Follow this and additional works at: https://digitalcommons.unl.edu/agronomyfacpub

Part of the Plant Sciences Commons

Akeson, W. R.; Gorz, H.J.; and Haskins, Francis A., "Sweetclover-Weevil Feeding Deterrent B: Isolation and Identification" (1969). Agronomy \& Horticulture -- Faculty Publications. 155.

https://digitalcommons.unl.edu/agronomyfacpub/155

This Article is brought to you for free and open access by the Agronomy and Horticulture Department at DigitalCommons@University of Nebraska - Lincoln. It has been accepted for inclusion in Agronomy \& Horticulture -Faculty Publications by an authorized administrator of DigitalCommons@University of Nebraska - Lincoln. 


\section{Sweetclover-Weevil Feeding Deterrent B: Isolation and Identification}

Abstract. Deterrent $B$, a compound apparently involved in the resistance of Melilotus infesta to the sweetclover weevil Sitona cylindricollis, has been isolated from leaves by a combination of preparative paper chromatography, sublimation, and crystallization. The compound has been identified as ammonium nitrate. Isolated deterrent $B$ and ammonium nitrate have identical feeding deterrent activities. Although the deterrent principle was isolated as the ammonium salt, nitrate ion is probably responsible for the deterrent activity in vivo.

The sweetclover weevil Sitona cylindricollis (Fåhraeous) is the major insect pest of sweetclover (Melilotus spp.) in the northern Great Plains of the United States. The adult insects feed on sweetclover leaves, leaving characteristic crescent-shaped notches. If present in large numbers, the weevils can completely defoliate young plants. One sweetclover species, $M$. infesta Guss., is resistant to weevil feeding (1).

A bioassay has been developed for the detection of factors which influence feeding by the sweetclover weevil (2). In the bioassay, washed disks of sweetclover root tissue are impregnated with the extracts to be tested and offered to adult weevils for feeding. The extent of feeding is measured by determining the percentage of disk area consumed during a given feeding period. In a bioassay of various extracts of leaves from the weevil-resistant $M$. infesta and a susceptible species, $M$. officinalis (L.) Lam., feeding was strongly stimulated by chloroform-soluble substances from both species. Also, water-methanol or water extracts of $M$. officinalis leaves stimulated extensive feeding in the bioassay system, but little feeding was observed on bioassay disks treated with corresponding extracts of $M$. infesta leaves $(2,3)$.

Bioassay of leaf extracts separated by chromatography has shown that $M$. infesta leaves contain at least three watersoluble substances which influence weevil feeding (4). Two of these substances, stimulant $\mathbf{A}$ and deterrent $\mathbf{A}$, apparently occur in both $M$. officinalis and $M$. infesta. The third, deterrent B, was detected only in $M$. infesta extracts. Available evidence indicates that deterrent $\mathbf{B}$ is involved significantly in resistance of $M$. infesta to weevil feeding. Deterrent B has now been isolated and identified as ammonium nitrate.

Young $M$. infesta leaves were autoclaved in water as described $(3,4)$ to provide an extract of which $5 \mathrm{ml}$ corresponded to $1 \mathrm{~g}$ of dry tissue. A 100-ml sample of crude extract was first sub- jected to preparative paper chromatography on Whatman No. $3 \mathrm{MM}$ filter paper with ascending solvents. Solvents, in order of use, were: (I) isopropyl alcohol-concentrated ammonium hydroxide-water (8:1:2); (II) isopropyl alcohol-glacial acetic acid-water (8: $1: 3$ ); and (III) methanol. Water was used to elute the deterrent $B$ band (location determined by bioassay) after each chromatographic step. After chromatography with methanol, the eluate containing deterrent $\mathbf{B}$ was lyophylized to dryness.

The powder obtained was next sublimed at $0.2 \mathrm{~mm}-\mathrm{Hg}$ and $100^{\circ} \mathrm{C}$. The sublimate was washed from the cold finger with a small quantity of methanol, and the resultant solution was transferred to a graduated centrifuge tube. Deterrent B was precipitated from the solution by the addition of five volumes of ethyl ether. After centrifugation ( $2000 \mathrm{~g}, 5$ minutes), the supernatant was decanted and the precipitate was taken up in a small volume of methanol. To

Table 1. Feeding deterrent activity of various levels of isolated deterrent $\mathbf{B}$ and ammonium nitrate. Quantities shown were mixed with a quantity of stimulant A extracted from $8 \mathrm{mg}$ (dry weight) of young $M$. officinalis leaves in a total of $0.15 \mathrm{ml}$ of $\mathrm{H}_{2} \mathrm{O}$. The resultant solution was applied to five bioassay disks. A single experiment consisted of five disks of each treatment offered to a population of two adult weevils per disk in a 145-mm petri dish as previously described (2). The percentages are means ( \pm S.E.) based on five such experiments.

\begin{tabular}{|c|c|c|}
\hline \multicolumn{2}{|c|}{ Treatment } & \multirow{2}{*}{$\begin{array}{l}\text { Disk area } \\
\text { consumed } \\
\qquad(\%)\end{array}$} \\
\hline $\begin{array}{l}\text { Quantity } \\
\text { (mg) }\end{array}$ & Substance & \\
\hline & $\underset{\text { (control) }}{\text { Stimulant }} \mathrm{A}$ & $56.1 \pm 3.1$ \\
\hline $\begin{array}{l}0.05 \\
0.05\end{array}$ & $\begin{array}{l}\text { Deterrent } \mathrm{B} \\
\mathrm{NH}_{4} \mathrm{NO}_{3}\end{array}$ & $\begin{array}{l}36.6 \pm 2.8 \\
35.9 \pm 2.4\end{array}$ \\
\hline $\begin{array}{l}0.10 \\
0.10\end{array}$ & $\begin{array}{l}\text { Deterrent } \mathrm{B} \\
\mathrm{NH}_{4} \mathrm{NO}_{3}\end{array}$ & $\begin{array}{l}17.0 \pm 2.5 \\
16.8 \pm 1.5\end{array}$ \\
\hline $\begin{array}{l}0.20 \\
0.20\end{array}$ & $\begin{array}{l}\text { Deterrent } \mathrm{B} \\
\mathrm{NH}_{4} \mathrm{NO}_{3}\end{array}$ & $\begin{array}{l}7.6 \pm 1.4 \\
6.6 \pm 1.1\end{array}$ \\
\hline $\begin{array}{l}0.40 \\
0.40\end{array}$ & $\begin{array}{l}\text { Deterrent } \mathrm{B} \\
\mathrm{NH}_{4} \mathrm{NO}_{3}\end{array}$ & $\begin{array}{l}1.4 \pm 0.5 \\
2.1 \pm 1.0\end{array}$ \\
\hline $\begin{array}{l}0.80 \\
0.80\end{array}$ & $\begin{array}{l}\text { Deterrent } \mathrm{B} \\
\mathrm{NH}_{4} \mathrm{NO}_{3}\end{array}$ & $\begin{array}{l}0.0 \pm 0.0 \\
0.0 \pm 0.0\end{array}$ \\
\hline
\end{tabular}




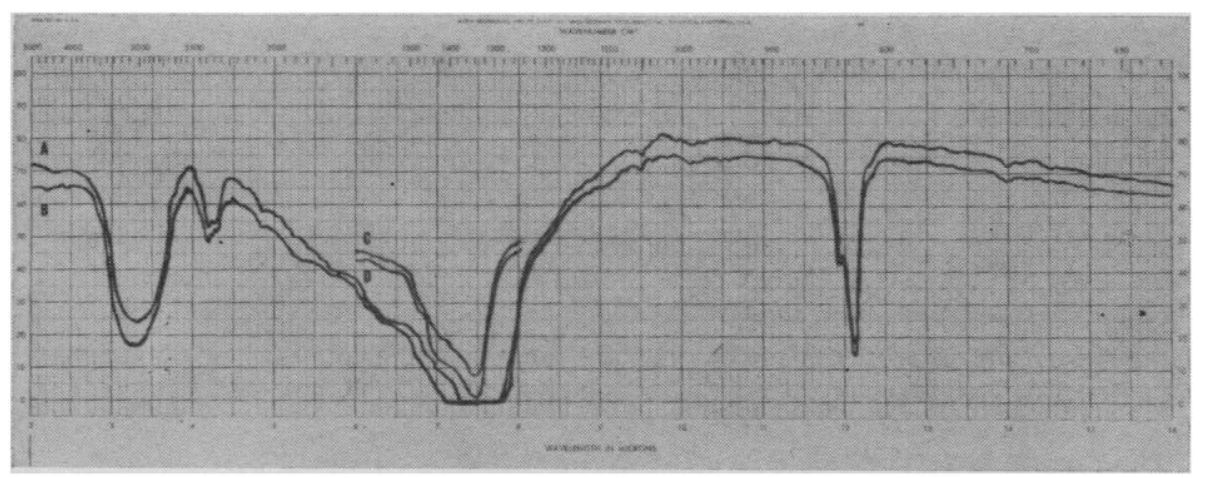

Fig. 1. Infrared spectra (determined with a Beckman model IR-5 spectrophotometer) of feeding deterrent $\mathrm{B}$ isolated from $\mathrm{M}$. infesta and of ammonium nitrate in $\mathrm{KBr}$ pellet. $(A)$ Deterrent $\mathrm{B}, 5 \mathrm{mg}$; $(B)$ ammonium nitrate, $5 \mathrm{mg} ;(C)$ deterrent $\mathrm{B}, 2 \mathrm{mg}$; and (D) ammonium nitrate, $2 \mathrm{mg}$.

the methanolic solution, $n$-butyl alcohol ( 0.1 volume) was added, and the solution was allowed to stand at room temperature. Upon standing, methanol evaporated from the solution and colorless, needle-like crystals formed. The crystals were further purified by two more crystallizations from the methanol-butyl alcohol system, after which they were washed once with butyl alcohol and twice with ethyl ether. Washed crystals were dried in a vacuum $(1 \mathrm{~mm}-\mathrm{Hg})$ at $40^{\circ} \mathrm{C}$ for 30 minutes to remove traces of ether. The yield of crystals from 100 $\mathrm{ml}$ of crude leaf extract was $48 \mathrm{mg}$.

Elemental analysis of the crystalline deterrent $B$ disclosed the following percentages: $\mathrm{H}, 5.31 ; \mathrm{O}, 59.31 ; \mathrm{N}, 32.30$; $C$, trace $(<1)$; and ash, trace. This composition corresponds reasonably well to that of ammonium nitrate (calculated percentages: $\mathrm{H}, 5.04 ; \mathrm{O}, 59.96$; and $\mathrm{N}, 35.00$ ). The isolated material melted at $169^{\circ}$ to $170^{\circ} \mathrm{C}$ (uncorrected, aluminum block) while known ammonium nitrate melted at $169.6^{\circ} \mathrm{C}$. The ultraviolet absorption spectra of aqueous solutions of deterrent $B$ and ammonium nitrate were identical, with molar extinction coefficients of approximately 15,400 and 7.0 , respectively, at the $204 \mathrm{~nm}$ and 303 $\mathrm{nm}$ absorption maxima. The infrared spectrum of deterrent $B$ also coincided with that of ammonium nitrate (Fig. 1). The $R_{F}$ values for deterrent B and ammonium nitrate, respectively, in the three solvent systems used in the initial purification steps were as follows (15-cm solvent ascent): solvent $\mathrm{I}-0.56,0.55$; solvent II- $0.55,0.53$; and solvent III$0.60,0.55$. Both deterrent $B$ and ammonium nitrate were detected on the chromatograms as absorbing spots under short-wavelength ultraviolet light (peak near $254 \mathrm{~nm}$ ). The feeding deterrent activity of the isolated compound was quantitatively similar to that of reagent grade ammonium nitrate at all levels of treatment (Table 1). Thus, the activity of isolated deterrent $B$ appears to be due to ammonium nitrate rather than to impurities which might be present in trace amounts.

On the basis of preliminary tests, the feeding deterrent activities of potassium nitrate and sodium nitrate appear to be very similar to that of ammonium nitrate. In addition, nitrate assays of young $M$. infesta leaves indicate a level five to ten times as high as that in comparable $M$. officinalis leaves. Therefore, the hypothesis is advanced that in young, intact leaves of $M$. infesta and in crude aqueous extracts of such leaves, nitrate ion is the feeding deterrent. The ammonium salt was probably formed during the first chromatographic purification, inasmuch as this step employed an ammoniacal solvent.

W. R. Akeson

F. A. Haskins H. J. GoRz

Department of Agronomy, University

of Nebraska, and Crops Research

Division, Agricultural Research Service, U.S. Department of Agriculture,

Lincoln, Nebraska 68503

\section{References and Notes}

1. G. R. Manglitz, H. J. Gorz, J. Econ. Entomol. 57, 683 (1964).

2. W. R. Akeson, G. R. Manglitz, H. J. Gorz W. R. Akeson, G. R. Manglitz, H.
F. A. Haskins, ibid. 60, 1082 (1967).

3. W. R. Akeson, H. J. Gorz, F. A. Haskins, G. R. Manglitz, ibid. 61, 1111 (1968).

4. W. R. Akeson, F. A. Haskins, H. J. Gorz, G. R. Manglitz, Crop Sci. 8, 574 (1968).

5. Cooperative investigations between the $\mathrm{Ne}$ braska Agricultural Experiment Station, University of Nebraska, and Entomology and Crops Research Divisions, Agricultural Research Service, U.S. Department of Agriculture; supported in part by grant No. 12-10-100-8027(33) from the Agricultural Research Service. Paper No. 2402, Journal Series, Nebraska Agricultural
Experiment Station.

25 October 1968 